Management / Olaf Bärenfänger, Erwin Tschirnen // Foreign Language Annals. - 2008. № 1. - P. 79-99. 3. Burge Bethan. European Survey on Language Competences: Language Proficiency in England / Bethan Burge, Ager Robert, Cook Rose, Cunningham Rachel, and others. - Department of Education, 2013. - 246 p. 4. Council of Europe. Relating Language Examinations in the Common European Framework of References for Languages: Learning, Teaching, Assessment (CEF). - 2003. - Strasbourg, France. 5. Dörnyei Zoltn. Motivation in Second and Foreign Language Learning / Zolt'n Dörnyei // Language Teaching. - 1998. № 3. - P. 117-135. 6. Edwards Viv. Globalization and Multilingualism: the Case of the UK / Viv Edwards // Intercultural Communication Studies. - 2011. - № 1. - P. 27-35. 7. GCSE Subject Criteria for Modern Foreign Languages. - Ofqual. - September, 2011 8. Paton Graeme. Fewer than Half of Pupils Take a Language GC5 / Graeme Paton // The Daily Telegraph. - 2007. - № 7. - P. 3. 9. Stromquist Nelly P. Globalization and Education: Integration and Contestation across Cultures / Nelly P. Stromquist, Monkman Karen. - Plymouth: R\&L Education, 2014. - 362 p. 10. Wiarda Howard J. Globalization: Universal Trends, Regional Implications / Howard J. Wiarda. - Lebanon : North-eastern University Press, 2007. - 286 p.

УДК 37.014 .5

Ганна Давиденко

\title{
РЕТРОСПЕКТИВНИЙ АНАЛІЗ УПРОВАДЖЕННЯ ІНКЛЮЗИВНОЇ ОСВІТИ В НІМЕЧЧИНІ
}

Давиденко Г. В. Ретроспективний аналіз упровадження інклюзивної освіти в Німеччині.

Статтю присвячено дослідженню питання про впровадження інклюзивної освіти у Німеччині. У статті розглянуто історичні віхи становлення інклюзивної освіти у Німеччині, окреслено законодавче підгрунтя та сучасний стан упровадження інклюзивного навчання для людей з інвалідністю.

Ключові слова: інклюзія, спеціальна освіта, інтеграція, інклюзивне навчання, інклюзивна освіта.

Давыденко А. В. Ретроспективный анализ внедрения инклюзивного образования в Германии.

Статья посвящена исследованию вопроса о внедрении инклюзивного образования в Германии. В статье рассмотрены исторические вехи становления инклюзивного образования в Германии, очерчена законодательная почва и современное состояние внедрения инклюзивного обучения для людей с инвалидностью.

Ключевые слова: инклюзия, специальное образование, интеграция, инклюзивное обучение, инклюзивное образование.

Davydenko H. V. The Retrospective Analysis of Introduction of Inclusive Education in Germany.

The article deals with the process of implementation of inclusive education in Germany. The historical landmarks of inclusive education formation in Germany are studied. The legislative background and modern state of inclusive education implementation for people with disability are outlined.

Key words: inclusion, special education, integration, inclusive studies, inclusive education. 
У зв'язку 3 подальшим утіленням в життя інклюзивної парадигми в освіті важливим $є$ аналіз досвіду й стратегій передових країн Європейського Союзу в цьому аспекті.

Філософські та педагогічні проблеми інклюзивної освіти знайшли своє висвітлення в працях вітчизняних науковців А. Колупаєвої, М. Матвєєвої, С. Миронової, Ю. Найди, Т. Сак, О. Таранченко та інших; американських А. Де Боера, В. Кагрейна, Дж.-Р. Кіма, М. Шмідта; британських - Т. Брендона, Дж. Чарльтона; шведських - Е.-Х. Маттсона, А. Хансен тощо. Незважаючи на велику кількість публікацій та монографічних праць у царині інклюзивної освіти, аспекти ії втілення в окремих країнах Європейського Союзу висвітлені фрагментарно, тому актуальним є аналіз й узагальнення імплементації інклюзії в низці країн: Франції Німеччині, Австрії, Італії тощо.

Метою статті є аналіз саме німецької моделі імплементації інклюзії, зокрема, історичні віхи інклюзії у ФРН, огляд законодавчих передумов цього процесу та опис сучасної концепції інклюзивної освіти в Німеччині.

На думку науковців, саме Німеччина була першою країною, де зародилися ідеї навчання дітей з обмеженими можливостями. Так, у Баварії 1198 року було відкрито притулок для сліпих [2]. Перші законодавчо закріплені вияви освіти на теренах Німеччини відносять до 70-х pp. XIX ст., коли було прийнято закон про загальну початкову освіту. Тоді ж у Лейпцігу біло відкрито першу школу для глухих. У червні 1933 р. А. Гітлер ініціював закон про запобігання спадкових хвороб, за яким навчання дітей з обмеженими можливостями призупинилося, а дорослі люди стерилізувалися.

Після Другої світової війни розпочався сучасний етап становлення інклюзивної освіти. У федеральних землях запроваджувалося відкриття «спеціальних шкіл для дітей 3 труднощами в навчанні» («Sonderschule für Lernbehinderte»). У 1971 році в Німеччині підписано Декларацію ООН «Про права розумово відсталих осіб», а в 1975 - «Про права інвалідів». 3 цього часу розбудовується мережа спецшкіл (Förderschule, Sonderschule, Förderzentrum) - для дітей 3 порушеннями опорнорухового апарату, мовлення, інтелектуальними порушеннями, емоційного розвитку тощо.

Реформування освітньої галузі відбулося в Німеччині, коли на початку 70-х років Міністерством у справах освіти, релігії і культури були прийняті нормативно-правові акти, які засвідчили, що кожна дитина 3 обмеженими можливостями має право на вибір навчального закладу, має бути забезпечена психолого-педагогічним супроводом, залучена до педагогічного процесу, незалежно від ступеню складності захворювання. У цей час громадська організація «Життєва допомога» розгорнула свою діяльність і вплинула на Міністерство у справах освіти, релігії й культури, яке прийняло нормативно-правовий акт «Рекомендації 3 організації спеціального навчання» (1972 р.). Згідно з ним запроваджувалися кооперативні форми навчання на всіх землях ФРН, за якими учні з вадами отримали можливість спільно зі здоровими брати участь у масових заходах, занять, отримання реабілітаційної допомоги та корекції. Незалежно від складності захворювання, діти могли обирати зручний навчальний заклад та отримувати необхідний педагогічний та психологічний супровід.

Цей закон конкретизувався у правовій системі окремих земель, де варіативно визначалася наявність спеціального педагога як асистента вчителя або ж можливість мати його в штаті школи як окремого фахівця. Прийнятий документ надав можливість розвитку «кооперативних» форм організації освітньої діяльності масових і 
спеціальних шкіл, що передбачають спільне проведення масових заходів, окремих навчальних занять, відвідування учнів 3 порушеним розвитком масової школи та надання їм корекційно-реабілітаційних послуг у спеціальному закладі тощо.

Наступні етапи розвитку інклюзї̈ у сфері освіти опираються на підписані 1989 року «Конвенцію про права дитини», 2006 року - «Конвенція про права людей 3 інвалідністю» («Convention on the Rights of Persons with Disabilities») [5].

На початку XXI ст. в Німеччині було прийнято Конвенцію ООН про права інвалідів, ратифікація якої розпочалася 2009 року. Вона передбачає, що до 2012 усі діти не залежно від фізичних і психологічних особливостей мають можливість відвідувати дитячі садки й школу. Процес охопив як розроблення законодавчої бази, так i конкретних методик роботи педагогів в інклюзивних групах. Важливим ментальним підгрунтям для розвитку інклюзивної освіти в Німеччині є лояльне й доброзичливе ставлення до інвалідів на побутовому рівні. Людей 3 обмеженими можливостями можна зустріти як у музеях, транспорті, культурних закладах, так і в усіх соціальних інститутах. Основний закон про освіту в Німеччині надає кожному громадянину право вільно розвивати свою особистість, вибирати школу чи місце навчання, професію за своїми здібностями й нахилами.

Керівні органи освіти в Німеччині - це Постійна конференція міністрів освіти й культури федеративних земель та Конференція ректорів вищих навчальних закладів. У кожній з федеративних земель керівництво освітнім сектором здійснюють земельні профільні міністерства. На основі загального Федерального закону тут діють власні закони про освіту. Якщо шкільна і вища освіта $\epsilon$ взаємопов'язаною багаторівневою державною структурою, то дошкільні заклади розвинені слабко й перебувають переважно у приватній власності.

У вирішенні питань психолого-педагогічного супроводу учнів 3 особливими потребами в умовах інклюзивного навчання Німеччину з поміж інших європейських країн вирізняє варіативність організації такого супроводу, яка зумовлена відмінностями в законодавстві Земель. В окремих Землях освітні нормативно-правові акти надають можливість школам мати у своєму штаті спеціальних педагогів та фахівців, які надають допомогу дітям 3 особливими потребами, в інших випадках спеціальні педагоги виконують функції асистента вчителя, співпрацюючи 3 педагогами класу.

Психолого-педагогічний супровід забезпечується педагогічними центрами, які функціонують у кожному регіоні, хоча форми організації роботи можуть бути різні. Центри надають різнопланову допомогу школярам 3 особливими освітніми потребами, проводять 3 ними профорієнтаційну роботу, координують діяльність різнопрофільних фахівців, консультують батьків та вчителів масових та спеціальних шкіл тощо. Окрім центрів підтримку учням з особливими потребами надають служби, що функціонують поза межами шкіл і фінансуються органами місцевого самоврядування. Це- медико-соціальні служби, ресурсні центри, реабілітаційні заклади тощо. Нині в Німеччині паралельно із системою спеціальних освітніх установ, де перебувають діти в основному зі складними порушеннями, функціонують заклади інклюзивного навчання.

Однією $з$ перших шкіл для дітей з вадами розвитку вважається берлінська школа імені Флеммінга, заснована в 70-ті pp. XX ст. Основним завданням iï є включена освіта дітей з порушеннями розвитку разом зі звичайними учнями. Крім спеціальних шкіл, ув Німеччині існують загальні школи, у яких поряд 3 повноцінними учнями в кожному класі навчаються 3-5 особливих дітей в тому числі одна дитина - на інвалідному візку. Перша з таких шкіл з'явилася в передмісті Берліна в 1999 році 
(школа Регіни Хільдебрандт, що об’єднує загальну школу зі спецшколою для сліпих). У цьому закладі інтеграцію вводять поступово шляхом злиття спеціальних класів із загальними за бажанням кожної дитини, яка має можливість інтегруватися у звичайний клас або довчатися у спеціальному.

Державне фінансування шкіл для дітей з особливими потребами складає в різних землях Німеччини близько $75 \%$. Решту $25 \%$ оплачують батьки за рішенням опікового комітету, створеного з батьків школи. На рівні школи дирекція виконує тільки загальні координувальні функції, а більшість повноважень лягає на плечі батьків.

Загалом Німеччина відстає від інших європейських країн в упровадженні інклюзивної освіти. Це пов'язано з тим, що нацистська політика щодо соціалізації неповноцінних дітей зруйнувала в середині XX ст. традиції інтегрованого навчання й виховання. У ті часи поширеною була так звана «нацистська евтаназія», згідно з якою проводилася політика «присипання» дефективних новонароджених як «зайвих їдців».

Законодавче забезпечення фінансування шкіл з інклюзивним підходом великою мірою спирається на повноваження муніципалітетів. Останні не тільки фінансують школи для підтримки інтегрованого навчання, а й сприяють благодійним акціям, лотереям, торгам і виставкам, які свою виручку здають у фонд навчального закладу.

На сучасному етапі в Німеччині реалізується проект (IQUA - Inklusion, Qualifikation, Assistenz), в рамках якого розпочато підготовку спеціалістів для інклюзивних закладів, що функціонують під гаслами «дитсадок для всіх», «школа для всіх» і передбачають спільне навчання здорових дітей 3 тими, хто має фізичні та психічні обмеження [9, с. 13]. Згідно з проектом передбачене переорієнтування навчальних кадрів та програм на спільний дидактичний процес дітей з різними психофізичними можливостями.

Уповноважений Федерального уряду у справах інвалідів ФРН Хуберт Хюппе зазначає, що незважаючи на прийняття Конвенції ООН 3 прав інвалідів досі в Німеччині до 80 \% дітей з особливими потребами навчаються окремо від здорових однолітків. За словами Хюппе, в Німеччині прийнято Національний план дій Міністерства праці й соціальної політики, у якому йдеться: «Ідея інклюзії, лейтмотив Конвенції ООН про права інвалідів має змінити нашу щоденну культуру. Німеччина стане інклюзивною» [1].

Як зазначає А. Смолонська, в Німеччині процес упровадження інклюзивної освіти на сучасному етапі передбачає розв'язання низки теоретичних і практичних проблем, а саме: подолання усталених стереотипів й педагогічних штампів і перехід від поняття інтеграція (передбачає поділ дітей на «нормальних» і дефективних) до поняття інклюзія; розширити поняття «інклюзія» при формулюванні педагогічної мети й забезпечити можливість відвідування найзручнішої і найближчої школи дитиною 3 обмеженими можливостями; забезпечення підготовки висококваліфікованих кадрів для інклюзивної освіти, в тому числі й помічників та асистентів при педагогах й нарешті подолання просторових та інституціональних бар'єрів, за наявності яких анулюється принцип «острівного життя» людей 3 обмеженими можливостями [4, с. 47-48].

Характерною ознакою становлення законодавчої системи щодо освіти неповносправних $\epsilon$ запровадження 3 початку 2000-х pp. у землях Німеччини федеральних законів про освіту. Так, у 2005 році в Північній Вестфалії затверджено Закон про освіту й Правила навчання дітей з обмеженими можливостями здоров'я як доповнення до Закону, який постулює обов'язкову середню освіту для дітей незалежно від їхніх можливостей, при чому батьки мають першочергове право на 
вибір форм навчання: а) в спецшколах; б) в загальноосвітніх школах зі спеціальними інтегративними уроками; в) в спецкласах; г) у звичайних класах $[7 ; 10]$.

У зазначеному Законі та його конкретизаціях постановлено забрати з назв шкіл нагадування про дефектність. Натомість до назви школи додається специфікація «розумовий розвиток» (Förderschwerpunkt Geistige Entwicklung).

15 червня 2011 року Парламент Німеччини ухвалив Національний план дій 3 реалізації Конвенції ООН про права людей з інвалідністю, у вступі до якого Урсула фон дер Лейєн, міністр праці й соціальних питань, озвучила головний девіз цього плану - «Einfach machen. Unser Weg in eine inklusive Gesellschaft» (Просто зробити. Наш шлях - в інклюзивне суспільство) [6]. За словами міністра, недосконалість обов'язкова ознака будь-якої людини, але вона не відміняє безліч можливостей, закладених у кожному. Інвалідність - один із виявів унікальності людини, а найкращий вихід боротьби 3 нею- бути в суспільстві й включатися в трудову діяльність.

Іншою політичною і законодавчою сферою освітньої підтримки молоді, що має обмежені можливості здоров'я в Німеччині, є молодіжна політика. Так, у червні 1990 року було прийнято закон «Про допомогу дітям і молоді», який замінив застарілий закон 1922 року «Про благодійну допомогу молоді». Документ зорієнтований на правове регулювання проблем соціального благополуччя молодих людей і передбачає інтеграцію в найширшому сенсі, починаючи від особистого добробуту - до інтегрованості в культурне й трудове середовище [3].

У Німеччині діє Соціальний кодекс, який координує молодіжну роботу, виховання дітей та молоді, сприяння денному вихованню й навчанню та допомогу психічно обмеженим дітям. Згідно кодексу, діти, що потребують спеціального соціального догляду поділяються на індивідуально обмежених (individuell beeinträchtigten)та соціально обділених (sozial benachteiligten) [8].

У ньому є спеціальний розділ «допомога при вихованні» («Hilfe zur Erziehung»), яка передбачає надання освітніх та супровідних терапевтичних послуг. Загалом кодекс $\epsilon$ юридичним регулюванням широкого спектру сервісів, зокрема: а) консультування 3 питань виховання (Erziehungsberatung); б) соціальну роботу в групах для подолання проблем розвитку й поведінки (Soziale Gruppenarbeit); в) наставницьку допомогу і виховну підтримку для подолання проблем розвитку й поведінки дітей старшого віку (Erziehungsbeistand und Betreuungshelfer); г) сімейну соціально-педагогічну допомогу (Sozialpädagogische Familienhilfe); допомогу 3 виховання в денній групі (Erziehung in einer Tagesgruppe); г) допомогу з постійного догляду (Vollzeitpflege); д) виховання дітей, проживання яких у домашніх умовах ускладнене через проблеми розвитку, у дитячих будинках дітей (Heimerziehung) [8].

Якщо дитина має порушення розвитку, що виявляється впродовж шести місяців або більше й перешкоджає іiі повноцінній участі в житті суспільства (або прогнозовано перешкоджатиме), то такі діти мають право на інтеграційну допомогу психічно обмеженим дітям (Eingliederungshilfe für seelisch behinderte Kinder und Jugendliche) [8].

Німеччина - перша країна, де зародилися ідеї навчання дітей з обмеженими можливостями, проте реальне законодавче забезпечення цього процесу відбулося у 70-х pp. ХХ ст. 3 прийняттям «Рекомендацій з організації спеціального навчання». У 2009 році ратифіковано Конвенцію ООН про права інвалідів, за якою з 2012 р. всі діти, незалежно від фізичних і психологічних можливостей, відвідують дитсадки і школи. У сучасній Німеччині реалізується проект (IQUA - Inklusion, Qualifikation, Assistenz), у рамках якого відкриваються інклюзивні заклади під гаслами «дитсадок 
для всіх», «школа для всіх», забезпечення яких спирається на повноваження муніципалітетів та діяльність Міністерства молодіжної політики.

Законодавче впровадження інклюзивної освіти в Німеччині розпочалося в кінці XIX ст. й набуло широких масштабів з 70-pp. XX ст. Німеччина належить до держав, у яких імплементація інклюзивної освіти здійснюється за принципом «зверху вниз», наявний чіткий розподіл функцій між державною та регіональною сферами управління освітою, держава бере на себе фінансування додаткових посад вчителів, витрат на дітей 3 особливими потребами (до $75 \%$ ), фінансування служб, що функціонують поза межами шкіл, запроваджує квоти на навчання неповносправних у закладах всіх рівнів і несе відповідальність за імплементацію інклюзії.

Перспективними в подальших наукових розвідках $є$ дослідження інклюзивної парадигми 3 проекцією на історичне становлення інклюзії в освітніх системах інших країн Європейського Союзу.

\section{Література}

1. Зарубежный опыт: интеграция инвалидов Германии в общественную жизнь [Электронный ресурс]. - Режим доступа: http://www.radugazvukov.ru/istok_audio_ trading/inclusive/news/?ELEMENT_ID=5730 2. Малофеев Н. Н. Западная Европа: эволюция отношения общества и государства к лицам с отклонениями в развитии / Н. Н. Малофеев - М. : «Экзамен», 2003. - 256 с. 3. Молодіжна політика у Німеччині [Електронний ресурс]. - Режим доступу : http://trendpolicy.ru/molodezhnaja-politika-vgermanii.html. 4. Смолонская А. Н. Основы организации инклюзивного образования в Германии [Електронний ресурс]/ А. Смолонская. - Режим доступу: http://mggush.ru/sites/default/files/smolonskaya.pdf 5. Convention on the rights of persons with disabilities (2006). [Електронний pecypc].- Режим доступу: (http://www.un.org/disabilities/documents/convention/convoptprot-e.pdf) 6. «Einfach machen». Unser Weg in eine inklusive Gesellschaft Nationaler Aktionsplan der Bundesregierung zur Umsetzung des Übereinkommens der Vereinten Nationen über die Rechte von Menschen mit Behinderungen (2011). [Електронний ресурс].- Режим доступу : http:/www.bmas.de/SharedDocs/Downloads/DE/2011_06_15_ nap.pdf?_blob= publicationFile. 7. Schulgesetz für das Land Nordrhein-Westfalen. Stand: 15. 4. 2011 (2011). [Електронний ресурс]. - Режим доступу : http://www.schulministerium.nrw.de/ BP/Schulrecht/Gesetze/ SchulG_I nfo/Schulgesetz.pdf. 8. Sozialgesetzbuch Achtes Buch Kinder- und Jugendhilfe [Електронний ресурс].- Режим доступу :http://bundesrecht. juris. de/sgb 8/. 9. Thalheim St. Inklusion im Kindergarten. Qualitätdurch Qualifikation, Reutlingen / St. Thalheim, J. Jerg., W. Schumann (Hrsg.) IQUA. Ev. Fachhochschule Reutlingen-Ludwigsburg, Diakonie Verlag, 2008 10. Verordnung über die sonderpädagogische Förderung, den Hausunterricht und die Schule für Kranke. Stand: 1. 7. 2010 (2010). [Електронний ресурс]. - Режим доступу: http://www.schulministerium. nrw.de/BP/ Schulrecht/APOen/AO_SF.pdf.

УДК 378. 147

Олена Драшко

\section{ОСОБЛИВОСТІ ПІДГОТОВКИ ВЧИТЕЛІВ ТЕХНОЛОГІЇ: РЕТРОСПЕКТИВНИЙ АНАЛІЗ}

Драшко О. М. Особливості підготовки вчителів технології: ретроспективний аналіз.

У статті сконцентровано досвід професійної підготовки вчителів технології в Україні та в Республіці Польща. Зосереджено увагу на розвитку системи підготовки 